\title{
The Dynamics of Global E-Commerce: an Organizational Ecology Perspective
}

\author{
Rajshekhar G. Javalgi \\ Cleveland State University, r.javalgi@csuohio.edu \\ Robert F. Scherer \\ Cleveland State University, r.scherer@csuohio.edu
}

Follow this and additional works at: https://engagedscholarship.csuohio.edu/busmarkt_facpub

Part of the Marketing Commons

How does access to this work benefit you? Let us know!

\section{Publisher's Statement}

(c) 2005 Emerald

\section{Original Citation}

Javalgi, R. (. G., Todd, P. R., , \& Scherer, R. F. (2005). The dynamics of global e-commerce: an organizational ecology perspective. International Marketing Review, 22(4), 420-435. doi:10.1108/ 02651330510608442

\section{Repository Citation}

Javalgi, Rajshekhar G. and Scherer, Robert F., "The Dynamics of Global E-Commerce: an Organizational Ecology Perspective" (2005). Marketing. 52.

https://engagedscholarship.csuohio.edu/busmarkt_facpub/52

This Article is brought to you for free and open access by the Browse Business Faculty Books and Publications by Topic at EngagedScholarship@CSU. It has been accepted for inclusion in Marketing by an authorized administrator of EngagedScholarship@CSU. For more information, please contact library.es@csuohio.edu. 


\title{
THE DYNAMICS OF GLOBAL E-COMMERCE: AN ORGANIZATIONAL ECOLOGY PERSPECTIVE
}

\author{
Rajshekhar (Raj) G. Javalgi, Cleveland State University \\ Patricia R. Todd, Lubrizol Corporation \\ Robert F. Scherer, Cleveland State University
}

This article was originally published in:

Javalgi, Rajshekhar G. and Patricia R. Todd et al (2005). The Dynamics of Global E-Commerce: an Organization Ecology Perspective. International Marketing Review, 22(4), 420-435.

Post-print standardized by MSL Academic Endeavors, the imprint of the Michael Schwartz Library at Cleveland State University, 2013

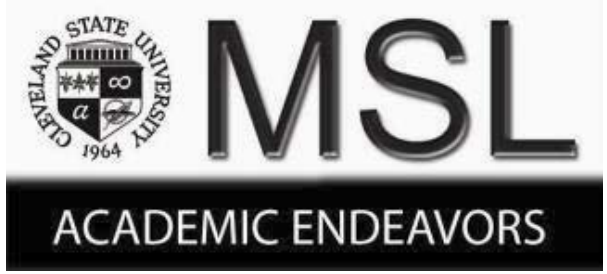




\title{
The dynamics of global e-commerce: an organizational ecology perspective
}

\author{
Rajshekhar (Raj) G. Javalgi \\ James J. Nance College of Business, Cleveland State University, Cleveland, \\ Ohio, USA \\ Patricia R. Todd \\ Lubrizol Corporation, Cuyahoga, Ohio, USA, and \\ Robert F. Scherer \\ James J. Nance College of Business, Cleveland State University, Cleveland, \\ Ohio, USA
}

\begin{abstract}
Purpose - A classical model of organizational ecology dynamics which is utilized to characterize an ecosystem called the internet is proposed and a parallel is drawn between the population ecology model and the current global e-commerce environment.

Design/methodology/approach - Survivorship theory is applied to global e-commerce. The Verhulst-Pearl logistic equation can be used to describe the inhibition of growth within an ecosystem. The approach is to apply the Verhulst-Pearl logistic equation to describe international growth dynamics of the internet.

Findings - When applying the Verhulst-Pearl equation to the internet environment around the world, the number of domain names or host counts, the rate at which there is an increase or decrease in the number of domain names, and the availability of information technology infrastructure are all factors that are part of the equation. The model of population dynamics presented in our discussion lends itself to the description of the current pattern of growth within the internet environment.

Practical implications - The application of population ecology to international growth dynamics describes the long-term survival and differentiation strategies that impact success. The next evolution of firms on the internet, which may be the ultimate survivors, should follow the path characterized as low cost producers with a focus on meeting the needs of the consumers on the internet. An ecological approach allows managers to ascertain the effectiveness of their organizations in the internet environment and accordingly devise strategies to embrace changes and challenges of the global environment.

Originality/value - The population ecology conceptual framework offers promise for a more sophisticated and methodologically rigorous approach to future investigations by both researchers and practitioners. The operationalization of the organizational ecology model for application to the internet is an extension of the literature.
\end{abstract}

Keywords Internet, Electronic commerce, Demographics

Paper type Conceptual paper

The authors would like to thank the Editor and anonymous reviewers for their suggestions and insights that have significantly improved this paper. 


\section{Introduction}

Advances in communication technologies within the last decade of the twentieth century paved the way for innovations promoting rapid globalization. The convergence of telecommunications and computer technology has given birth to a new business organizational system called the internet, presenting a revealing example of ecological business development. The internet represents a new and important technology that has received much media focus and attention from academicians, entrepreneurs, business executives, and investors (Kobin, 2001; Lumpkin et al., 2002; Lynch and Beck, 2001; Oxley and Yeung, 2001; Porter, 2001; Sawhney and Zabin, 2002). The development of e-commerce, enabled through the internet as a conduit, suggests both the birth of a new business environment, and the possibility of catastrophic change within the old environment. The coming of the information age and the advent of the internet have resulted in changes, requiring a reevaluation of organizational models used to describe business management. Hannan and Freeman (1977) developed the foundation of organizational ecology in an attempt to explain the existence of organizations. Since then, organizational ecologists have theorized that environmental pressures significantly impact the success of an organization with regard to its form, function, and overall strategy. A critical evaluation of the growth of e-commerce on the internet provides a unique opportunity to examine the natural evolution of a business sector that was created and colonized over a relatively short time period.

Unequivocally, the internet technology and its various manifestations (e.g. e-commerce) provide better opportunities for companies around the world to establish distinctive strategic advantages (Kotha et al., 2001; Varadarajan and Yadav, 2002). However, there are challenges to effectively utilizing this new medium for business purposes (Dunning and Wymbs, 2001; Lynch and Beck, 2001). Some of the challenges include the modeling of the evolution of the internet's development from inception.

In the current discussion, we present a classical model of population ecology dynamics to characterize an ecosystem called the internet (Hannan and Freeman, 1977; Zammuto, 1988). We propose there are features that are parallel between the population dynamic model and the current e-commerce environment. The underlying dynamics of competition and change management impacting e-business follow a pattern that can be compared to competition and adaptation strategies found within nature. Global managers' interest in the internet is apparent by activities that are undertaken throughout the world to support its use (Globerman et al., 2001). We propose that problems in e-commerce, although in many cases exacerbated by poor management practices, may have also been inevitable as part of a natural selection process. We argue that concepts describing population dynamics can be transferred and used to describe the current turmoil that is evident in the internet environment. The study of population dynamics focuses on the births and deaths (e.g. mergers and acquisitions, bankruptcies) of organizations in an environment (Freeman and Boeker, 1984). Our overall objective is to operationalize the ecology model for application to the internet. A second objective is to examine the international growth of the internet, specifically by emphasizing issues surrounding the dynamics of survivorship.

Our discussion is organized as follows. Section 2 presents conceptual background providing the foundation for the application of the organizational ecology model. Section 3 discusses survivorship theory as applied to global e-commerce. Future research, as well as implications and conclusions, are provided in Sections 4 and 5. 


\section{Organizational ecology: conceptual background}

In their recent article Sammut-Bonnici and Wensley (2002) present a comprehensive review of evolutionary theories as they relate to organizational change. Their literature review provides a foundation for the development of research questions pertaining to the adoption of evolutionary analogies to explain organizational change. During the 1980s, research was conducted by organizational theorists to further develop and broaden the application of population ecology models to the evolution of firms (Beard and Dess, 1988; Betton and Dess, 1985; McKelvey and Aldrich, 1983; Wholey and Brittain, 1986, 1989; Zammuto, 1988). Crawford and Tellis (1981) extended the product life cycle concept to include the evolutionary aspects of product growth, and the development of the product evolutionary cycle. Population dynamics were used to describe the development of organizational strategies (Freeman and Boeker, 1984; Hannan and Freeman, 1977; Zammuto, 1988). Ecological models were applied to organizations in an effort to derive answers to questions concerning their differentiation, their strategies for adapting to environmental change, and the characteristics that are evolutionary (McKelvey and Aldrich, 1983).

Organizational ecology investigates selection processes impacting organizational populations which, under specific environmental conditions, parallel patterns of change that are found in biotic populations (Singh and Lumsden, 1990). The primary thesis supporting organizational ecology is that once an organization is born, it is subjected to inertial pressures resulting in changes that are part of the demographic processes of birth through death. Carroll (1984) identified three basic levels of analysis of these processes: the organizational level, the population level, and the community level. According to Carroll (1984), research at the population level is "defined as population ecology, concentrates on population growth and decline as well as on interactions between multiple populations. Evolutionary theory is integrated with ecology at this level through the use of selection”. In the discussion Caroll's focus is on the population level of organizations. At this level, the evolution of populations can be observed by examining the impact of environmental conditions on the rates of organizational births, deaths and adaptations. Of particular interest is the phenomenon of density dependence. Delacroix and Carroll (1983) propose that, over time, the creation of organizations follows a cyclical pattern that can be explained by the availability of resources within the environment. Economic concepts are expressed in terms of self-organization dynamics that have been derived from basic evolutionary concepts (Buenstorf, 2000). Regional carrying capacities, in terms of local inputs and infrastructures, were seen as a limiting factor in industrial development (Gambarotto and Maggioni, 1998). Mascarenhas and Sambharya (1996) extended the population ecology framework to include international competition and legitimation over time in the airline and oil drilling industries. Carroll and Delacroix (1982) supported the idea that populations of industrial organizations follow a pattern similar to the one found occurring in natural environments.

In organizations, the availability of resources and the density, in terms of the numbers of organizations, early on determine the rate at which new organizations are born (Hannan, 1988).

The definition of population, within an organizational context, used in our discussion is consistent with that proposed by Hannan and Freeman (1977). A population consists of an aggregate of organizations operating within the internet 
environment. An important factor impacting the future growth of populations is density. Density refers to the size of a population in relation to its unit of space. The carrying capacity is the limit imposed by the ability of the environment to provide resources to support the population (Delacroix and Carroll, 1983). Moreover, carrying capacity is the level where the available resources can support a population at survival and which is influenced by the most limiting resource (Smith and Smith, 2001). An ecosystem is considered a self-renewing group of producers, consumers and decomposers, who survive within a common area and share resources (Prendergast and Berthon, 2000). According to Moore (1993) "a business ecosystem, like its biological counterpart, gradually moves from a random collection of elements to a more structured community. Business ecosystems condense out of the original swirl of capital, customer interest, and talent generated by a new innovation, just as successful species spring from the natural resources of sunlight, water, and soil nutrients". As the density of organizations increases, the competitive process begins to take over and the rate of new entrants decreases (Hannan, 1988).

\subsection{Organizational ecology models}

The mathematical formula below, the Verhulst-Pearl logistic equation, can be used to describe the inhibition of growth within an ecosystem (Zammuto, 1988).

$$
\frac{\mathrm{d} N}{\mathrm{~d} t}=r N\left[\frac{K-N}{K}\right]
$$

In this case $\mathrm{d} N / \mathrm{d} t$ is the instantaneous rate of change where $N$ is the number of individuals in a population, $K$ is the carrying capacity and $(K-N) / K$ is the unutilized opportunity for population growth (Zammuto, 1988). The $r$ is the reproductive rate of the population (Zammuto, 1988). The rate of population growth over time is equal to the potential increase of the population times the unutilized portion of resources (Smith and Smith, 2001). One measure of the growth of e-commerce within various countries is the increase in the number of domain names or host counts. Top-level domain (TLD) names are represented by internet addresses that end in two letters that represent country codes. The letter combinations are established using the International Organization for Standardization (ISO) list of English country names and code elements. For example, a domain name ending in .ar represents Argentina; de represents Germany and .ca represents Canada (www.iso.org/iso/en/prods-services/ iso3166ma/02iso-3166-code-lists/list-en1.html). There are a few limitations that have been identified using this method that should be kept in mind. The first is that the domain name does not give an indication of the size of the host or the nature of the business (Jordan, 2001). The second is that there is a possibility that the host has a registered domain in an indicated country but may not actually be located there (Jordan, 2001). The latter problem has occurred, but is not a major anomaly.

The increase in TLD registrations, along with spending on information technology and services, is suggested for use as an indicator of e-commerce growth and stability (Zook, 2000; Moss and Townsend, 1997; Jordan, 2001; www.witsa.org/papers/ EComSurv.pdf; www.oecd.org/dataoecd/11/25/2091083.pdf). Therefore, when applying the Verlhurst-Pearl equation to the internet environment around the world, $N$ would be the number of domain names or host counts, $r$ would be the rate at which there is an increase or decrease in the number of domain names, and $K$ would be the availability of 
information technology infrastructure, which would consist of the number of available phone lines and PCs, for example. When $N$ (the number of domain names) is small or nearly zero, that is, $(K-N) / K$ approaches unity, most of the resources are unutilized and the population grows. When $N$ is equal to $K$, that is $(K-N) / K$ approaches zero, most of the resources are used and therefore the population grows very little. If $N$ is larger than $K$, then $\mathrm{d} N / \mathrm{d} t$ is negative and the population decreases due to lack of available resources. Once this occurs, the population level will decrease to a point below the carrying capacity (or until resources are again available). This is important when considering the pattern of internet growth as it relates to the increase in domain names region by region.

The Verhulst-Pearl equation describes a logistic growth curve as shown in Figure 1. The figure illustrates the pattern of rapid growth, followed by decline and the cyclical nature of growth as the carrying capacity becomes the limitation. In a business environment, several ecosystems may compete for dominance and survival (e.g. Dell and Gateway in the PC ecosystem; Amazon, Barnes and Noble in the book retailing ecosystem). Successful and innovative businesses do not evolve in a vacuum, but endeavor to attract necessary resources such as suppliers, customers and capital, which are necessary to survive and grow (Moore, 1993). In the competing environment survival depends on $r$ and $K$ selection in the ecosystem. Organizations following an $r$ strategy will move quickly into a niche in order to take advantage of abundant resources while $K$ strategists focus on competing within densely populated environments (Brittian and Freeman, 1980).

\subsection{Survivorship theory}

Central to the understanding of population growth is the concept of density dependence. Betton and Dess (1985) note that the primary conceptual components of the population ecology models in the study of organizations focus on the role of environmental factors in determining the survival of organizations. Selection theory is useful in explaining the dynamics of competition as it relates to global e-commerce. Selection of the new or changed organizational forms occurs as a result of environmental constraints. Competitive forces in a population are derived from the

Figure 1.

Expected growth pattern based on population dynamics

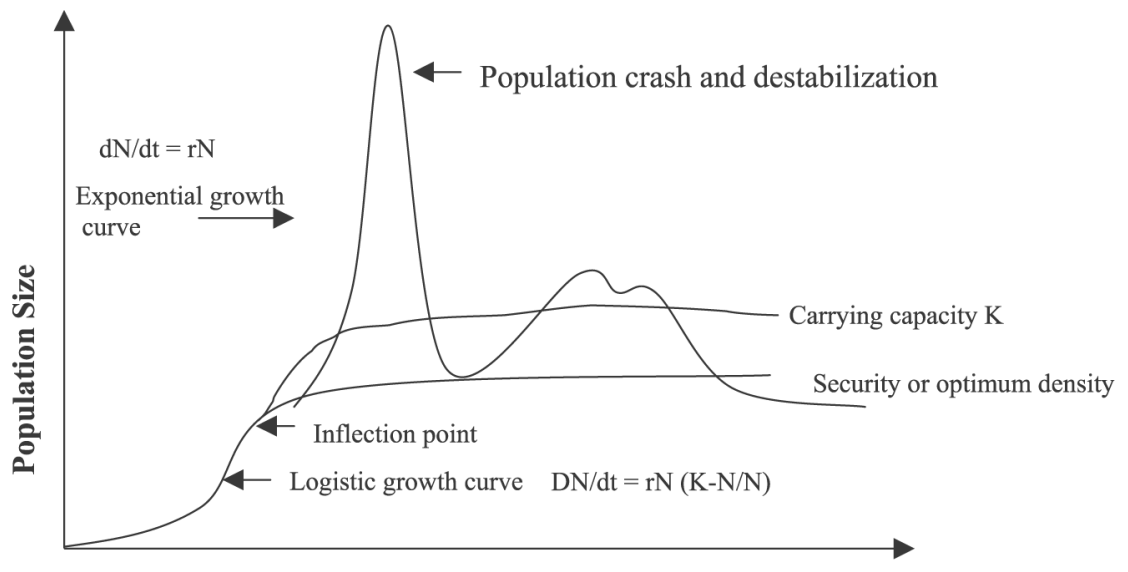

Time 
number of organisms competing for a limited number of resources available to the population.

In a scenario where the population is relatively new, there is an abundance of resources and the growth of one competitor may not impact that of another (MacArthur and Wilson, 2001). As the population density increases, resources become scarce and it becomes more difficult to avoid direct competition because more organisms are competing for a limited number of resources. As competition for available resources intensifies, organisms that are less efficient and unable to adapt to the new environment will not survive. While this was undoubtedly manifested in the demise of the dot.coms, the same concept applies to organizations as they compete for market share using available resources. Successful, innovative businesses are those that do not evolve in a vacuum, but strive to attract additional resources such as capital, partners, suppliers, and customers (Moore, 1993). The ability to survive and adapt to the changing environment requires investing organizational resources (e.g. capital and employee time) and such decisions, to a large extent, are influenced by the selection of $r$ and $K$ in the ecosystem.

Table I compares and contrasts the differences between populations that are dominantly $r$-strategists versus those that are focused on $K$-selection. As can be seen in the table, natural selection in saturated environments ( $K$-selection) favors offspring with greater competitive ability, those that can compete based on efficient use of existing resources. Perhaps the most far-reaching evolutionary effect of interspecific competition is ecological diversification, also termed niche specification. Another effect

\begin{tabular}{lll}
\hline Environmental factor & $r$ selection & $K$ selection \\
\hline $\begin{array}{l}\text { Climate } \\
\text { Uncertain } \\
\text { Constant and predictable }\end{array}$ & $\times$ & \\
Mortality & $\times$ \\
High & & \\
Low & & $\times$ \\
Population size & $\times$ & \\
Below carrying capacity & & \\
Saturated & & \\
Competition & $\times$ & \\
Lax, variable & & \\
Keen & & \\
Life span & & \\
Short & & \\
Long & $\times$ & $\times$ \\
Nature of new progeny & & Slower development \\
& Rapid development & Greater competitive ability \\
& High rate of increase & Delayed reproduction \\
Leads to & Early reproduction & Larger size \\
& Small size & Repeated reproduction \\
& Single production & Efficiency
\end{tabular}

Table I. Environmental factor and strategy selection 
of competition between species, as well as within species, is to increase the efficient utilization of resources. Because there is a limit to available resources, all organisms are competing for the same habitat. In order to maintain the population, the organism must find ways to more efficiently utilize available resources, otherwise the population will decline. Those species that evolve in this manner will survive. $K$-strategists are focused on the efficient use of available resources in a highly competitive environment. The $r$-strategists are focused on reproduction. The factor that determines the rate of population growth as the market matures is the $K$ term (Lambkin and Day, 1989). The applicability of $r$ and $K$ selection to organizational evolution has been demonstrated by Brittian and Freeman (1980). Firms that primarily follow the $r$ strategy are those that quickly move in to take advantage of being first to market, while $K$-strategists follow and gain competitive advantage through their efficiencies.

\subsection{Ecosystems and global e-commerce}

In the internet environment, the number of businesses occupying cyberspace is analogous to the population. Each individual business operating within the internet impacts the strategy of other businesses operating within the same market. For the sake of clarity, Table II provides a comparison between the characteristics of businesses and ecosystems. From the table, it can be seen that there are several parallels between newly-formed ecosystems and the internet business environment.

Both are populated at a relatively fast rate with a variety of individuals, whether they are species in the ecosystem or businesses on the internet. The environment for both is characterized by a significant amount of instability and movement, whether within a group of biological organisms or by the interactions between fledgling businesses. Considered an adaptation for surviving in an unstable or unpredictable environment, $r$-strategists are found in resource rich ecosystems in the early stages of succession and fluctuate with time and degrees of competition (Flegr, 1997). If the environment is characterized as stable or predictable, $K$-strategy would be considered the optimum adaptation (MacArthur and Wilson, 2001).

Biological systems evolve towards efficiency, with survival of the species dependent upon the organism's ability to adapt to changing environments. For the species to continue to flourish, it must make the most efficient use of resources. It is in

Table II.

Similarities between ecosystems, standard business, and e-commerce

\begin{tabular}{|c|c|c|c|}
\hline \multicolumn{2}{|c|}{ Ecological perspective } & \multicolumn{2}{|c|}{ Management perspective } \\
\hline Established ecosystem & New ecosystem & Standard business & E-commerce \\
\hline Self-contained system & $\begin{array}{l}\text { Imperceptible } \\
\text { boundaries }\end{array}$ & Self-contained system & $\begin{array}{l}\text { Imperceptible } \\
\text { boundaries }\end{array}$ \\
\hline Stable & In flux & Stable & In flux \\
\hline Active within itself & Interactive & Active within itself & Interactive \\
\hline Moderate diversity & Highly diverse & Moderate diversity & Highly diverse \\
\hline $\begin{array}{l}\text { Well-defined } \\
\text { boundaries }\end{array}$ & $\begin{array}{l}\text { Open to outside } \\
\text { influence }\end{array}$ & $\begin{array}{l}\text { Well-defined } \\
\text { boundaries }\end{array}$ & $\begin{array}{l}\text { Open to outside } \\
\text { influence }\end{array}$ \\
\hline $\begin{array}{l}\text { Low exchange of } \\
\text { species }\end{array}$ & $\begin{array}{l}\text { High exchange of } \\
\text { species }\end{array}$ & $\begin{array}{l}\text { Low exchange of } \\
\text { companies }\end{array}$ & $\begin{array}{l}\text { High exchange of } \\
\text { companies }\end{array}$ \\
\hline Changes driven within & $\begin{array}{l}\text { System interactions } \\
\text { drive change }\end{array}$ & Changes driven within & $\begin{array}{l}\text { System interactions } \\
\text { drive change }\end{array}$ \\
\hline
\end{tabular}


this manner that the analogy to the ecological aspect of the theory is made. Organizational theorists stress the importance of the role of the environment in determining the survival of organizations (Betton and Dess, 1985). Organizations change as a result of environmental, in this case density dependent, constraints. Lack of response to environmental changes, organizational inertia, is a potential contributor to a firm's inability to adapt and ultimately survive.

Freeman and Boeker (1984) empirically tested the proposition, explicit in population ecology models, that the survival of organizations is determined by environmental variations. Exit and entry strategies, as they relate to a business system's carrying capacity and the speed at which firms move to equilibrium have been investigated (Carree and Thurik, 1999). Marketing systems can adapt by replacing company presidents, changing strategic orientation, and modifying the technologies used to accomplish the mission of the organization in order to develop a competitive posture. Competition, within behavior systems, consists of finding a differentiated position that gives an overall advantage to one rival over another, resulting in a wider range of product and service variety or producing products based on exact customer specifications which is the precursor of niche marketing (Green, 1999). The overall ecological system will survive as long as the constituent members are meeting their goals (Nicosia, 1962).

\section{Survivorship theory as applied to global e-commerce \\ 3.1 Survivorship theory and global e-commerce}

Survivorship theory, or $r$ and $K$ selection, refers to selection strategies in colonization. The rate of increase or overall decrease in the number of businesses operating on the internet can be measured and is essentially the determination of $r$. On the other hand, the $K$ term of the equation can be measured by change in the size of the companies in terms of an organization's on-line revenues, the diversity of online businesses, or number of employees supporting the e-commerce effort. On the internet, a number of firms have recently collapsed and the carrying capacity for e-commerce has come into question. Companies that have been successful on the internet have established an infrastructure focusing on the core business and then expanded into other areas, following the expected growth pattern characterized by $K$-strategists.

Figure 2 utilizes the model for the Verlhurst-Pearl logistic equation to provide an illustration of regional internet growth, where the increase in the number of domain names is represented on the $y$-axis. The figure shows estimates of the relative position of each geographic region based on the stage of internet maturity exhibited within the region, relative to the growth in domain names (www.ngi.org/trends/TrendsPR0102. txt). While many regions are on the growth curve below the probable carrying capacity, it appears that the USA is on the downward slope, headed toward a decline in growth followed by lesser fluctuation, until eventual equilibrium is reached (Hayes, 2002). Asia is on the way up the population curve, with the entrance of many new companies within their internet domain. South America, the Middle East, and Africa are just beginning to grow, based on the establishment of the necessary infrastructure and consumer usage of computer services.

Although the current situation in Europe is still somewhat clouded, it is possible, based on our prediction, that Europe has also overshot carrying capacity and may be headed for retrenchment. The key question focuses on the other regions of the world. 


\section{8}

Figure 2.

Estimates of the relative position of geographic regions based on stage of internet maturity in 2002

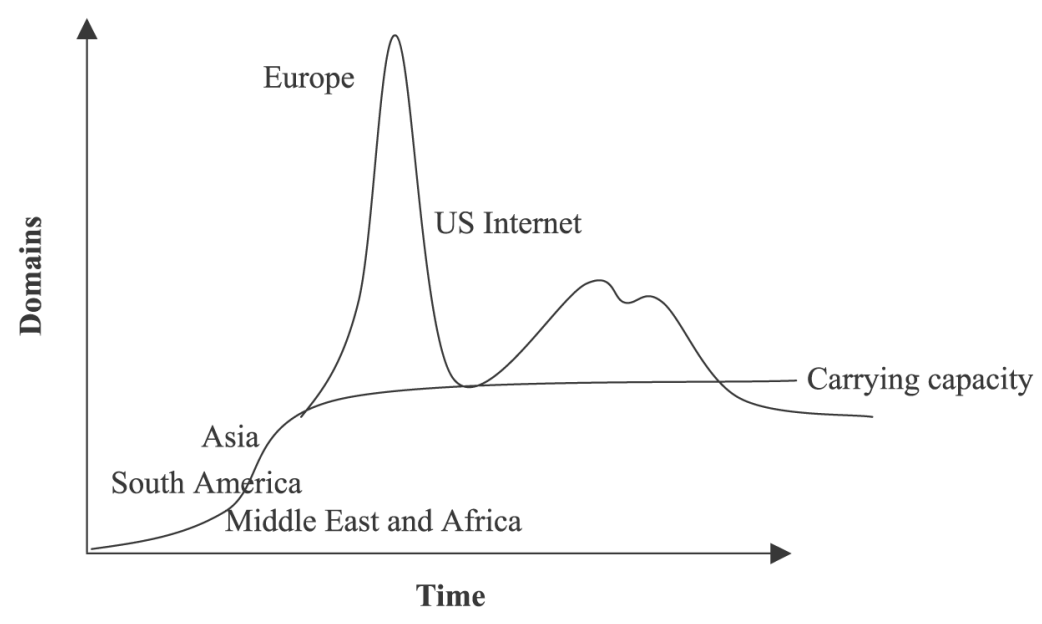

Will they follow the traditional curve of boom and then bust, or will they perceive the internet differently with a small number of firms pursuing slower growth? The ecological model would predict that the US internet environment will move towards the presence of fewer separate companies and an evolution toward larger firms.

Population dynamics can be used to describe the change in the internet environment, particularly in the developed countries and regions such as the USA and Europe. As the number of resources is diminished, the number of businesses declines, but the size of an individual surviving business increases. This is the relationship that would be predicted using a model of traditional population dynamics within a natural ecosystem. Using Figure 1 as an illustration of the growth in companies operating on the internet, the parallel between the growth pattern in nature and the growth in business becomes clear. In the pre-colonization stage (Stage 1) the early invaders of the internet environment were faced with virtually unlimited resources and no competition. Consistent with the characteristics of $r$ selection, the internet became populated with a large number of smaller individual companies that wanted to take advantage of the seemingly unlimited strategic resources such as capital, distribution, and computer and telecommunication services. Unfortunately as more and more businesses enter the arena, the resources begin to favor those businesses that evolve or adapt by partnering or expanding their product offerings. An example of an $r$-strategist turned $K$-strategist is Amazon. Amazon.com was one of the first entrants onto the internet and was focused exclusively on becoming a book retailer. The company established a business model, then grew and, as other companies exited, began expanding into other product areas (Chakrabarti and Scholnick, 2002).

As companies begin to fail, the selection strategy begins to move down the $r$ and $K$ continuum towards Stage 2, which is characterized by a reduction in the number of total individual businesses. Inadequate capital along with other necessary resources results in the death of businesses that are unable to adapt to increased competition. Examples of companies that have fallen during this stage are Pets.com, Garden.com, and MotherNature.com (Davis, 2000; Schultz and Schultz, 2001). The year 2000 was a crucial year for dot.com companies. Many retailers, for example, shut their operations facing the risk of their stock being de-listed on the stock market, while most venture 
capitalists and other financiers reconsidered the attractiveness of investment (Mahajan et al., 2002). Over 130 internet businesses declared bankruptcy or closed their doors in 2000 (Watson, 2001). Another 450 internet firms fell from January to April, 2001 (www. webmergers.com/data/article.php?id =67). A benchmarking report by e-Europe indicated that that the slower than expected growth in e-commerce can be attributed to a plateauing of internet penetration, consumer shipping, costs and lack of consumer confidence in the security of transactions (www.eubusiness.com/imported/2002/09/ 90145). The growth of the internet has often been referred to as a bubble and it seems that the bubble has burst (Coltman et al., 2001). Internet stocks have generally continued to loose value as the NASDAQ returns to levels seen prior to the internet frenzy.

Stage 3 is characterized by consolidation of companies and the formation of larger individual firms. Evidence of this phenomenon can be found by evaluating the strategy of Amazon.com (Kotha, 1998). E-Bay and Yahoo! are also examples of companies that have successfully survived the passage through the stages. AutoTrader.com, 401KExchange.com, and eAutoclaims.com have remained in business, in part, by building critical partnerships (DeVoe, 2002). In 1997, there were over 500,000 registered domain names given to companies worldwide with over 75 million businesses in Asia, Europe, and the Americas (Schrader, 1997). It was also estimated that within ten years, 24 million businesses would be connected to the internet (Schrader, 1997). This has all the appearances of an internet population that was indeed well below its carrying capacity. More recently, there are signs of slower growth (Hamilton and Mangalindan, 2000). A number of firms have collapsed as the carrying capacity comes into question.

Based on the $r$ and $K$ selection models, the final stage of the colonization cycle should be dominated by organizations meeting the characteristics of $K$-strategists. As the number of businesses decrease, competition is reduced and as indicated by the final stage, equilibrium is reached. After equilibrium is reached, the business environment becomes stable, cycling around the carrying capacity. These companies have survived because they have successfully adopted the $K$-strategy. This was accomplished by growing through product line extension and strategic alliances. Consistent with the dynamics of $r$ and $K$ selection, international internet growth would consist of expansion of existing web companies in terms of product offerings, rather than an increase in smaller individual entities. This is already evident in the strategy of Amazon.com (Chakrabarti and Scholnick, 2002). This organization began as a bookseller and then as the foundation became more stable, expansion occurred into a variety of other offerings, including partnering with retail outlets such as Target. Amazon.com has expanded alliances with other retailers to 16 (Mahajan et al., 2002). Using this strategy, the firm has significantly broadened product offerings over time, growing and utilizing resources characteristic of a $K$-strategist. The prediction has been made that online businesses will be dominated by either large online superstores, with a variety of product offerings, or online stores that have a large market share of a particular product niche (The Economist, 2000).

\subsection{Forces impacting the carrying capacity of the global internet}

The internet ecosystem encompasses a complex web of infrastructure, requiring cooperative work and competitive support of the ecosystems. There are several determinants that can influence the growth of the internet in general, and global 
e-commerce in particular, in developing and developed countries. For example, in Europe the costs associated with telecommunications are five times more than in the USA, and the number and availability of PCs is low (Shern, 2000). Another limiting resource is the absence of infrastructure. The telephone network, shipping capabilities, and the economic stability of a country can all act as limiting resources for increased internet growth. In the USA, which has the necessary infrastructure, the limiting resources are the availability of capital and the extent of consumer demand. During the rapid growth stage, internet companies were receiving large infusions of monetary support from venture capitalists. Much like the unlimited supply of nutrients initially available to a species in a new environment, businesses that were part of the first generation on the internet reproduced rapidly. As venture capitalists began to pull back their support, businesses that were unable to evolve "died," while newer entrants became fewer and fewer.

There are several other factors that can determine the carrying capacity of the internet within an international domain. Building blocks identified as strategically indispensable for the growth of e-commerce include social infrastructure, communication and computer access, commercial transactions, government policies, and distribution processes (Javalgi and Ramsey, 2001; Zaheer and Manrakhan, 2001). Other structural issues include computer literacy, language, information management, and consumer discontent (Samiee, 2001). Another resource consideration that significantly impacts the carrying capacity is the availability of capital in terms of finances. Obviously, those companies with greater financial resources are better positioned to cement their position within the internet environment (Hayes, 2002).

If the population growth curves for the USA are used as a template for the expected market dynamics of the internet environment, then the prediction of how the internet business population, in countries which may be considered developing in terms of internet access, can be accomplished. Forecasters predicted that by the end of 2002, there would be over 490 million worldwide internet users and almost double that by the year 2005 (www.cyberatlas.internet.com/big_picture/geographics/article/0,5911_ 151151,00.html). The estimated change in internet users for the USA saw a 27 percent decline as compared to earlier numbers (www.cyberatlas.internet.com). This may be an indication that the internet ecosystem, within the domain of the USA, has surpassed its carrying capacity and is going through the downward cycle to reach equilibrium.

Based on cross-country comparisons, it appears from these numbers that the internet population is indeed still well below the carrying capacity on a worldwide basis. Even though there is overall rapid growth of e-business, there are also signs of slower growth in some regions of the world (Hamilton and Mangalindan, 2000). A number of firms have recently collapsed and the carrying capacity for e-commerce has come into question. Two conditions that are important to meet in order to do business on the internet are a suitable infrastructure for communications and the support of the local business culture. Even though cyberspace seems like an environment with unlimited resources, there is a carrying capacity consisting of the availability of crucial resources. An understanding of the limiting factors that will impede uncontrolled growth on the world wide web will aid in building a more realistic business model for entering the global marketplace. 


\section{Future research}

Researchers in multiple disciplines, including management, have relied on ecological models to understand and predict the competitive dynamics within a business sector. It has been stated that the population ecology model offers a useful theoretical approach, specifically when analyzing the taxonomy of organizations (Betton and Dess, 1985). The question that remains unanswered deals with how organizations become different. Using the perspective gained from an understanding of population growth strategies may aid in developing models that answer this question.

Ecological models have been purported to explain the dynamics of living systems. Continuous changes and fluctuations in the environment (e.g. exploitation, competition, survival, and growth) represent selective forces upon the population to which it must adapt. Adaptation to the environment is imperative in order grow, sustain, and be successful in the internet era, where the only constant is change. From a conceptual point of view, our discussion contributes to the literature, demonstrating the fact that organizational populations of businesses on the internet have grown and changed in a manner consistent with the organic growth found in the colonization of a new ecosystem.

There are many research challenges to this important field of information and communication technology. We estimated the carrying capacities in the USA, Europe, and other geographic regions in the world (Figure 2). In the "real" world, more accurate estimates are needed, with details for industries and product lines. The current state of technology, as it relates to carrying capacity, also requires additional investigation.

Identification and definition of the limiting factors that impact the carrying capacity of the global internet is an area that requires further development. A possible constraint is the inability of consumers to deal with the vast numbers of businesses operating on the internet. Being overwhelmed by the choices available, a consumer chooses to deal with a company based on size, experience, and word of mouth testimonials. New entrants cannot compete. They fail or become part of a larger organization.

Empirical studies are needed to ascertain the degree to which internet businesses follow the ecological model; especially, identification of factors that both derive and inhibit the success of e-commerce firms in both developing and developed economies. A comprehensive, empirically testable framework that measures and predicts the birth and mortality rates within the global internet warrants attention. Another research avenue to consider concerns organizational characteristics (e.g. size of company, resources, and management structure) that change over time and allow a company to survive. Is there a common thread that can be identified that ensures longevity on the internet? We acknowledge that the theory presented in our discussion is abstract without consideration given to different business sectors, models, and measurability and scalability issues. Methodologically, future research should acknowledge that differences among the growth rate of various business sectors on the internet are affected by environmental pressures consistent with those found in competitive situations in nature. Another way to further develop the $r$ and $K$ model within the e-commerce sector is to develop a measurement system that would estimate the probability of failure or success of individual organizations on the internet. 


\section{Implications and conclusion}

Researchers assert that the internet enables new international companies immediate access to customers and suppliers around the world (Quelch and Klein, 1996). The business issue that has led to the application of population ecology to international growth dynamics on the internet is identification of a model that describes the long-term survival and differentiation strategies that impact success. The next evolution of firms, which may be the ultimate survivors, should follow the path of the $K$-strategists. These companies will be the low cost producers with a focus on meeting the needs of the consumers on the internet. The successful companies will put their energies into efficiency and collaboration within the internet ecosystem. Internet companies may merge together, broaden their product offerings, and appear larger to the consumer.

In the internet ecosystem, many overnight successes turned into failures unparalleled in history. Was this rapid increase and subsequent decline in the numbers of businesses entering the internet environment a result of a business model that was not viable, the lack of methodologies for assessing the market value, or the lack of management expertise and experience of the dot.com management teams (Mahajan et al., 2002)? Another possibility is that the growth and decline was part of the natural selection process that is seen in any ecosystem in which a new population or species is introduced. Can an evolutionary model, based on ecological population dynamics, be constructed that assists businesses to better understand and predict internet business dynamics?

In conclusion, models that were developed to predict the dynamics in ecological systems have been applied to the business environment in previous research. Moore (1993) notes that every business ecosystem develops in different stages (e.g. birth, expansion, leadership, self-renewal, or death). Each stage presents unique managerial challenges and opportunities in the ecosystem. The internet represents the startup of a new ecosystem that is rapidly growing and can be evaluated from its inception. Further, it is a new system and no one expected that it would grow at an unprecedented rate and change the existing international market boundaries swiftly. Hamill (1997) has appealed for a reevaluation of the results of prior research and for the development of a new international management paradigm.

The model of population dynamics presented in our discussion lends itself to the description of the current pattern of growth within the internet environment. It also has the potential to predict the pattern of growth as the internet ecosystem spreads into international territories. Using an ecological approach, managers can ascertain the effectiveness of their organizations in the internet environment and accordingly devise strategies to embrace changes and challenges of the global environment, where the only constant is change. We believe that the population ecology conceptual framework offers promise for a more sophisticated and methodologically rigorous approach to future investigations by both researchers and practitioners.

\section{References}

Beard, D.W. and Dess, G.G. (1988), "Modeling organizational species' interdependence in an ecological community: an input-output approach", Academy of Management Review, Vol. 13 No. 3, pp. 362-73. 
Betton, J. and Dess, G.G. (1985), "The application of population ecology models to the study of organizations”, Academy of Management Review, Vol. 10 No. 1, pp. 750-7.

Brittian, J. and Freeman, J. (1980), “Organizational proliferation and density dependent selection”, in Kimberly, J.R. and Miles, R.H. (Eds), The Organization Life Cycle, Jossey-Bass, San Francisco, CA, pp. 291-338.

Buenstorf, G. (2000), "Self-organization and sustainability: energetics of evolution and implications for ecological economics", Ecological Economics, Vol. 33 No. 1, pp. 119-34.

Carree, M.A. and Thurik, A.R. (1999), "The carrying capacity and entry and exit flows in retailing”, International Journal of Industrial Organization, Vol. 17 No. 7, pp. 985-1007.

Carroll, G.R. (1984), “Organizational ecology”, Annual Review of Sociology, Vol. 10, pp. 71-93.

Carroll, G.R. and Delacroix, J. (1982), "Organizational mortality in the newspaper industries of Argentina and Ireland: an ecological approach”, Administrative Science Quarterly, Vol. 27 No. 2, pp. 167-98.

Chakrabarti, R. and Scholnick, B. (2002), "International expansion of e-retailers: where the Amazon flows", Thunderbird International Business Review, Vol. 44 No. 1, pp. 85-104.

Coltman, T., Devinney, T.M., Latukefu, A.S. and Midgley, D.F. (2001), "E-business: revolution, evolution, or hype?", California Management Review, Vol. 44 No. 1, pp. 57-87.

Crawford, M.C. and Tellis, G.J. (1981), "An evolutionary approach to product growth theory”, Journal of Marketing, Vol. 45 No. 4, pp. 125-32.

Davis, J. (2000), "Dot-com casualty list mounts as holiday season approaches", Infoworld, Vol. 22, p. 32.

Delacroix, J. and Carroll, G.R. (1983), "Organizational foundings: an ecological study of the newspaper industries of Argentina and Ireland”, Administrative Science Quarterly, Vol. 28, pp. 274-91.

DeVoe, D. (2002), "Surviving the shakeout”, Infoworld, Vol. 24, pp. 42-3.

Dunning, J.H. and Wymbs, C. (2001), "The challenge of electronic markets for international business theory", International Journal of the Economics of Business, Vol. 8, pp. 273-301.

(The) Economist (2000), "Survey of e-commerce", The Economist, 26 February.

Flegr, J. (1997), "Two distinct types of natural selection in turbostat-like and chemo-stat-like environments", Journal of Theoretical Biology, Vol. 188, pp. 121-6.

Freeman, J. and Boeker, W. (1984), "The ecological analysis of business strategy", California Management Review, Vol. 26 No. 3, pp. 73-86.

Gambarotto, F. and Maggioni, M.A. (1998), "Regional development strategies in changing environments: an ecological approach”, Regional Studies, Vol. 32 No. 1, pp. 49-61.

Globerman, S., Roehl, T.W. and Standifird, S. (2001), "Globalization and electronic commerce: inferences from retail brokering”, Journal of International Business Studies, Vol. 32 No. 4, pp. 749-68.

Green, P. (1999), The Wroe Alderson Memorial Lecture Series, available at: http://hops.wharton. upenn.edu/news/info/wroe_alderson.html

Hamill, J. (1997), “The internet and international marketing”, International Marketing Review, Vol. 14 Nos 4/5, pp. 300-23.

Hamilton, D.P. and Mangalindan, M. (2000), "Angels of death, reality bites hard as string of dot coms sees funding dry up”, The Wall Street Journal, 25 May, pp. A1.

Hannan, M.T. (1988), "Organizational population dynamics and social change", European Sociological Review, Vol. 4 No. 2, pp. 95-109. 


\section{THE DYNAMICS OF GLOBAL E-COMMERCE}

Hannan, M.T. and Freeman, J. (1977), "Population ecology of organizations", American Journal of Sociology, Vol. 82 No. 5, pp. 929-64.

Hayes, M. (2002), “E-business loses momentum”, Informationweek, No. 893, p. 52.

Javalgi, R. and Ramsey, R. (2001), "Strategic issues of e-commerce as an alternative global distribution system”, International Marketing Review, Vol. 18 No. 4, pp. 376-91.

Jordan, T. (2001), "Measuring the internet: host counts versus business plans", Information, Communication and Society, Vol. 4 No. 1, pp. 34-53.

Kobin, S. (2001), "Territoriality and the governance of cyberspace", Journal of International Business Studies, Vol. 32 No. 4, pp. 687-704.

Kotha, S. (1998), "Competing on the internet: the case of Amazon.com”, European Management Journal, Vol. 16 No. 2, pp. 212-22.

Kotha, S., Rindova, V.P. and Rothaermel, F.T. (2001), "Assets and actions: firm specific factors in the internationalization of US internet firms", Journal of International Business Studies, Vol. 32 No. 4, pp. 769-92.

Lambkin, M. and Day, G.S. (1989), "Evolutionary processes in competitive markets: beyond the product life cycle", Journal of Marketing, Vol. 53 No. 3, pp. 4-20.

Lumpkin, G.T., Droege, S.B. and Dess, G.G. (2002), "E-commerce strategies: achieving sustainable competitive advantage and avoiding pitfalls", Organizational Dynamics, Vol. 30 No. 4, pp. 325-40.

Lynch, P.D. and Beck, J.C. (2001), "Profiles of internet buyers in 20 countries: evidence for region specific strategies”, Journal of International Business Studies, Vol. 32 No. 4, pp. 723-48.

MacArthur, R.H. and Wilson, E.O. (2001), Theory of Island Biogeography, University Press, Princeton, NJ.

McKelvey, B. and Aldrich, H. (1983), "Populations, natural selection, and applied organization science", Administrative Science Quarterly, Vol. 28 No. 1, pp. 101-29.

Mahajan, V., Srinivasan, R. and Wind, J. (2002), “The dot.com retail failures of 2000: were there winners?", Journal of the Academy of Marketing Science, Vol. 30 No. 4, pp. 474-86.

Mascarenhas, B. and Sambharya, R.B. (1996), "The pattern of density dependence in two global industries", Management International Review, Vol. 36 No. 4, pp. 331-54.

Moore, J.F. (1993), "Predators and prey: a new ecology of competition", Harvard Business Review, No. 3, pp. 75-86.

Moss, M. and Townsend, A. (1997), "Tracking the net: using domain names to measure the growth of the internet in US cities", Journal of Urban Technology, Vol. 4 No. 3, pp. 47-60.

Nicosia, F.M. (1962), "Marketing and Alderson's functionalism", Journal of Business, Vol. 35, pp. 403-13.

Oxley, J.E. and Yeung, B. (2001), "E-commerce readiness: institutional environment and international competitiveness", Journal of International Business Studies, Vol. 32 No. 4, pp. 705-23.

Porter, M.E. (2001), "Strategy and the internet”, Harvard Business Review, No. 3, pp. 63-78.

Prendergast, G. and Berthon, P. (2000), "Insights from ecology: an ecotone perspective of marketing”, European Management Journal, Vol. 18 No. 2, pp. 223-31.

Quelch, J.A. and Klein, L.R. (1996), "The internet and international marketing”, Sloan Management Review, Vol. 37 No. 3, pp. 60-75.

Samiee, S. (2001), "The internet and international marketing: is there a fit?", in Richardson, P. (Ed.), Internet Marketing-Readings and Online Resources, McGraw-Hill, Boston, MA. 
Sammut-Bonnici, T. and Wensley, R. (2002), "Darwinism, probability, and complexity: market-based organizational transformation and change explained through the theories of evolution", International Journal of Management Reviews, Vol. 4 No. 3, pp. 291-315.

Sawhney, M. and Zabin, J. (2002), "Managing and measuring relational equity in the network economy", Journal of the Academy of Marketing Science, Vol. 30 No. 4, pp. 313-32.

Schrader, W.L. (1997), "Why the internet crash will never happen”, Telecommunication, Vol. 31 No. 1, pp. 25-6.

Schultz, H.F. and Schultz, D.E. (2001), "Why the sock puppet got sacked", Marketing Management, Vol. 10 No. 2, pp. 34-9.

Shern, S. (2000), "Global online retailing: an Ernst and Young special report”, Stores, Vol. 83 No. 1, pp. 1-142.

Singh, J.V. and Lumsden, C.J. (1990), “Theory and research in organizational ecology”, Annual Review of Sociology, pp. 161-95.

Smith, R.L. and Smith, T.M. (2001), Ecology and Field Biology, 6th ed., Cummings, San Francisco, CA.

Varadarajan, P.R. and Yadav, M.S. (2002), "Marketing strategy and the internet: an organizing framework", Journal of the Academy of Marketing Science, Vol. 30 No. 4, pp. 296-312.

Watson, N. (2001), "Not a creature was stirring, not even a mouse”, Fortune, Vol. 143 No. 2, p. 33.

Wholey, D.R. and Brittain, J.W. (1986), "Organization ecology: findings and implications", Academy of Management Review, Vol. 11 No. 3, pp. 513-33.

Wholey, D.R. and Brittain, J.W. (1989), "Characterizing environmental variation”, Academy of Management Journal, Vol. 32 No. 4, pp. 867-82.

Zaheer, S. and Manrakhan, S. (2001), "Concentration and dispersion in global industries: remote electronic access and the location of economic activities", Journal of International Business Studies, Vol. 32 No. 4, pp. 667-85.

Zammuto, R. (1988), "Organizational adaptation: some implications of organizational ecology for strategic change”, Journal of Management Studies, Vol. 25 No. 2, pp. 105-20.

Zook, M. (2000), "Internet metrics: using host and domain counts to map the internet", The International Journal on Knowledge Infrastructure Development, Management and Regulation, Vol. 24 Nos 6/7.

\section{Further reading}

Schluter (2001), "Ecology and the origin of the species", Trends in Ecology and Evolution, Vol. 16, pp. 372-80.

Smith, R.L. (1974), Ecology and Field Biology, 2nd ed., Harper and Row, New York, NY. 